\title{
Amine Oxidase [Flavin-Containing] B
}

National Cancer Institute

\section{Source}

National Cancer Institute. Amine Oxidase [Flavin-Containing] B. NCI Thesaurus. Code C125505.

Amine oxidase [flavin-containing] B (520 aa, $\sim 59 \mathrm{kDa}$ ) is encoded by the human MAOB gene. This protein is involved in the deamination of amines. 